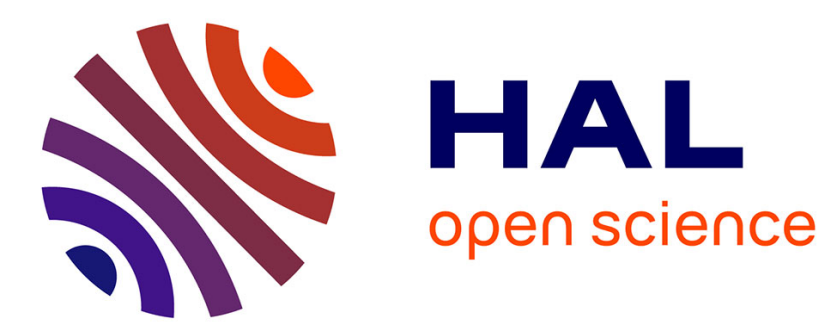

\title{
DESORPTION OF SECONDARY NEGATIVE IONS INDUCED BY FAST HEAVY INCIDENT ATOMIC AND MOLECULAR IONS
}

\author{
Mehran Salehpour, J. Hunt
}

\section{To cite this version:}

Mehran Salehpour, J. Hunt. DESORPTION OF SECONDARY NEGATIVE IONS INDUCED BY FAST HEAVY INCIDENT ATOMIC AND MOLECULAR IONS. Journal de Physique Colloques, 1989, 50 (C2), pp.C2-155-C2-158. 10.1051/jphyscol:1989226 . jpa-00229424

HAL Id: jpa-00229424

https://hal.science/jpa-00229424

Submitted on 1 Jan 1989

HAL is a multi-disciplinary open access archive for the deposit and dissemination of scientific research documents, whether they are published or not. The documents may come from teaching and research institutions in France or abroad, or from public or private research centers.
L'archive ouverte pluridisciplinaire HAL, est destinée au dépôt et à la diffusion de documents scientifiques de niveau recherche, publiés ou non, émanant des établissements d'enseignement et de recherche français ou étrangers, des laboratoires publics ou privés. 
DESORPTION OF SECONDARY NEGATIVE IONS INDUCED BY FAST HEAVY INCIDENT ATOMIC AND MOLECULAR IONS(1)

M. SALEHPOUR ${ }^{(2)}$ and J.E. HUNT

200 CHM, Argonne National Laboratory, 9700 South Cass Avenue, Argonne, IL 60439., U.S.A.

\section{RESUME}

ies ions lourás atorliques et rioléculaires ont été utilisés comme ions incidents dans des ¿tudes de désorption d'ions secondaires. Des ions $\mathrm{C}^{+}, \mathrm{C}_{2}+, \mathrm{C}_{3}+\mathrm{Ar}^{+}, \mathrm{CH}^{+}, \mathrm{CH}_{3}{ }^{+}, \mathrm{C}_{3} \mathrm{H}_{3}^{+}$, $\mathrm{C}_{4} \mathrm{H}_{9}+, \mathrm{C}_{7} \mathrm{H}_{15^{+}}, \mathrm{CO}^{+}, \mathrm{O}_{2}^{+}, \mathrm{CO}_{2}+, \mathrm{CF}^{+}, \mathrm{CF}_{3}+, \mathrm{C}_{3} \mathrm{~F}_{5}+$ and $\mathrm{C}_{4} \mathrm{~F}_{7}+$ ont étê produits et accélérés dans la gamme d'énergie $600 \mathrm{keV}-3.9 \mathrm{MeV}$. Les ions moléculaires ont des rendements de désorption ¿levés. Ceci présente un intérêt pratique en spectromètrie de masse. Une interprétation de 1 'augmentation du rendement est présentée.

\section{ABSTRACT}

Fast heavy atomic and molecular ions have been used as incident ions in secondary ion desorption studies. A number of ions such as $\mathrm{C}^{+}, \mathrm{C}_{2}+, \mathrm{C}_{3}+, \mathrm{Ar}^{+}, \mathrm{CH}^{+}, \mathrm{CH}_{3}+\mathrm{C}_{3} \mathrm{H}_{3}+, \mathrm{C}_{4} \mathrm{H}_{9}^{+}$, $\mathrm{C}_{7} \mathrm{H}_{15}{ }^{+}, \mathrm{CO}^{+}, \mathrm{O}_{2}+, \mathrm{CO}_{2}{ }^{+}, \mathrm{CF}^{+}, \mathrm{CF}_{3}{ }^{+}, \mathrm{C}_{3} \mathrm{~F}_{5}+$ and $\mathrm{C}_{4} \mathrm{~F}_{7}+$ have been produced and accelerated in the energy range $600 \mathrm{keV}-3.9 \mathrm{MeV}$. The molecular incident ions give rise to high measured secondary ion yields which is of practical interest in mass spectrometry. An interpretation of tile enhancement in the yield with molecular incident ions is presented.

\footnotetext{
(1) Work performed under the auspices of the Office of Basic Energy Sciences, U.S. Department of Energy under contract number $W-31-109-E N G-38$

(2) Present Address : Department of Radiation Sciences, Ion Physics Division, Box 533, Uppsala University. Uppsala, Sweden
} 
Particle induced desorption of polyatomic ions from surfaces is of general theoretical interest, as well as having practical applications in the field of mass spectrometry. A large body of experimental data exist on the use of fast ( $v>v_{\text {Bohr }}$ ) atomic incident ions in desorption studies (1). However, few reports exist on the use of fast molecular ions as the primary ions in desorption experiments. Brown et al. (2) and Thomas et al. (3) have used hydrogen cluster ions to measure the yields of $\mathrm{H}_{2} \mathrm{O}$ and $\mathrm{Cs}^{+}$ions respectively (yield is defined as the number of the species of interest desorbed per incident ion). We recently reported on desorption experiments with the use of fast heavy molecular ions such as $\mathrm{C}^{+}$, $\mathrm{C}_{2}+, \mathrm{C}_{3}+\mathrm{Ar}^{+}, \mathrm{CH}^{+}, \mathrm{CH}_{3}^{+}, \mathrm{C}_{3} \mathrm{H}_{3}^{+}, \mathrm{C}_{4} \mathrm{H}_{9}^{+}, \mathrm{C}_{7} \mathrm{H}_{15}+\mathrm{CO}^{+}, \mathrm{O}_{2}+\mathrm{CO}_{2}+\mathrm{CF}^{+}, \mathrm{CF}_{3}+, \mathrm{C}_{3} \mathrm{~F}_{5}{ }^{+}$and $\mathrm{C}_{4} \mathrm{~F}_{7}{ }^{+}$, in the energy range $600 \mathrm{keV}-3.9 \mathrm{MeV}(4,5,6,7)$.

The experimental set up is explained in detail elsewhere (7) and will not be discussed here in any detail. The ions are produced in an electron-ionisation ion source located at the high voltage terminal of a 4.5 MV Dynamitron accelerator. The accelerated molecular ions are unambigously identified and reach the time-of-flight (TOF) mass spectrometer. The secondary ion yields are measured using conventional Tof techniques. The standard sample has been the amino acid valine $(1 \mid W=117)$ electrosprayed on a thick stainless steel plate. The results presented here are limited to negative secondary ions since the secondary electrons have been used to trigger the start pulse for the TOF measurements.

Figure 1 shows the negative secondary molecular ion yield of valine, $Y$, as a function of the velocity of the primary $\mathrm{C}^{+}, \mathrm{C}_{2}+, \mathrm{C}_{3}+$ incident ions. From the relative secondary ion yields of valine, $Y$, as a result of impact with $C^{+}, C_{2}+$ and $C_{3}{ }^{+}$, it is apparent that non linearities exist; the secondary ion yield of valine molecular ions for incident $\mathrm{C}_{2}{ }^{+}$, $Y\left(C_{2}+\right)$ is much more that twice that for atomic carbon, i.e., $Y\left(C_{2}+\right) \gg 2 . Y\left(C^{+}\right)$. Similarly $Y\left(C_{3}+\right) \gg 3 . Y\left(C^{+}\right)$.

We have empirically determined that $Y\left(C^{+}\right)$for val ine negative molecular ions scale with the square of the electronic stopping power, $\frac{d E}{d x}(6,7)$. Such a relationship would then predict for molecular ions; $Y\left(C_{2}{ }^{+}\right) \approx 4 . Y\left(C^{+}\right)$and $Y\left(C_{3}{ }^{+}\right) \approx 9 . Y\left(C^{+}\right)$. However, the experimental point show much higher ratios over a range of primary ion velocities, i.e., approximately $Y\left(C_{2}{ }^{+}\right) \approx 8 . Y\left(C^{+}\right)$and $Y\left(C_{3}{ }^{+}\right) \approx 18 . Y\left(C^{+}\right)$. Similar results have been obtained with other incident ions such as $\mathrm{C}^{+}$and $\mathrm{O}^{+}$in comparison with $\mathrm{CO}^{+}$and $\mathrm{O}_{2}+(7)$. It thus seems that other processes may be present. 


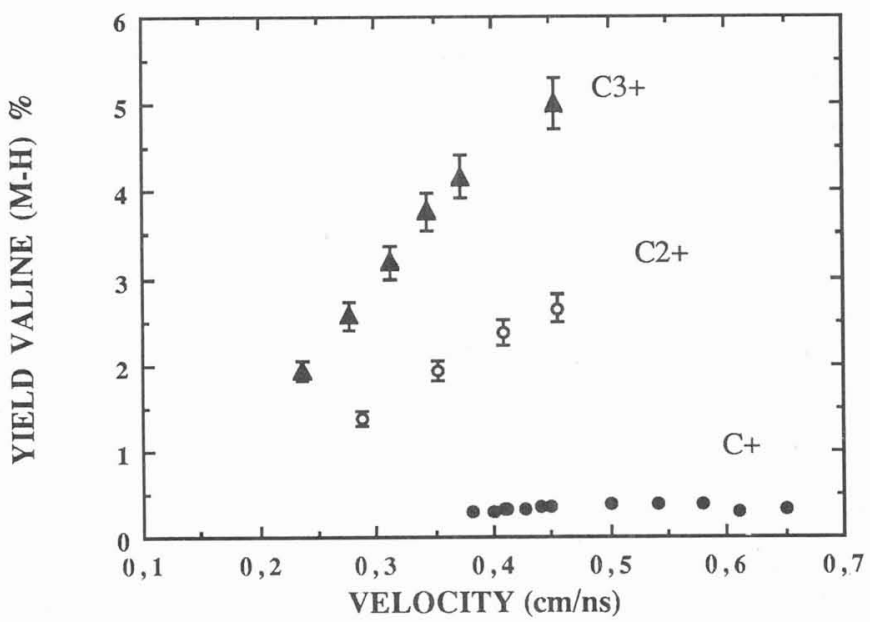

It has been shown experimentally that the electronic stopping power of an atom in a fast moving cluster in solids is higher in magnitude than the sum of the stopping powers of the atomic constituents in the same medium. The enhancement in $\frac{d E}{d x}$ per atom $X$ in a cluster $x_{n}$ was defined by Brandt (8) to be, $R=\frac{\frac{d E}{d x}\left(x_{n}\right)}{\sum \frac{d E}{d x}\left(x_{i}\right)}$. Brandt et al reported $R$ values in the range $1-1.5$ for $\mathrm{H}_{2}+$ and $\mathrm{H}_{3}+$ in thin carbon films. Tape et al. (9) have obtained similar results for $\mathrm{H}_{2}+$ and $\mathrm{O}_{2}$ - incident ions. The enhancement in $\frac{\mathrm{dE}}{\mathrm{dx}}$ was interpreted as being a "collective" effect due to the temporal and spatial correlation of the fast moving charges giving rise to an interference term in the total electronic stopping power of the cluster (8).

As discussed in detait in references (7), the desorption depth is comparable to the depth required for the incident molecular ions to separate completely and thus, any enhancemnts in $\frac{d E}{d x}$ would be reflected in desorption yields. The desorption data can be described by assuming a quadratic dependence on $\frac{d E}{d x}$ and using $R$ values in the range 1.1-1.4 for all of the experimental points. This is comparable to the $R$ values reported by Tape et al. (9) for $0_{2}$ - incident ions in the same velocity range as our experiment.

Preliminary results with another sample with different chemical properties, chlorophyll a $(M W=893)$ showed the same enhancements as valine ions. Hedin et al. (10) recently have reported desorption experiments with $\mathrm{C}_{2}+$ incident ions at a velocity of $0.49 \mathrm{~cm} / \mathrm{hs}$. Their valine negative ion data are in qualitative agreement with ours; they obtained $R=1.2+0.1$. However, for positive valine molecular ions they found $R=1$ (the conclusions are however, rather sensitive to the choice of $\frac{d E}{d x}$ ). Since any enhancements in $\frac{d E}{d x}$ are expected to be due to the distant collisions (8) (and not the close collisions), such differences between the 
positive and negative secondary ions might present a clue as to the their different origins. More experimental results are needed to clarify this.

The implications of this work are two-fold. First, with the large incident molecular ions such as $\mathrm{C}_{7} \mathrm{H}_{15}{ }^{+}$and $\mathrm{C}_{4} \mathrm{~F}_{7}{ }^{+}$, high secondary ion yields have been measured (up to 60 times that with atomic carbon) which could be of practical interest in mass spectrometry. Second, negative ion desorption studies might be useful in the future for studying the interaction of cluster incident ions with solids.

\section{REFERENCES}

(1) For a review, see B.U.R. Sundqvist and R.D. Macfarlane, Rev. Mass Spectrom. 4 (1985) 421

(2) H.L. Brown, W.M. Augustyniak, E. Simmons, K.J. Ifarcantonio, L.J. Lanzerotti, R.E. Johnson, J.W. Boring, C.T. Reiman, G. Foti and V. Pirronello, Nucl. Instr. lleth. $198(1982) 1$.

(3) J.P. Thomas, M. Fallavier, P.E. Filpus-Luycfx and E.A. Schweikert, Phys. Rev. Lett. $\underline{55}$ (1985) 103.

(4) I1. Salehpour, D.E. Fishel and J.E. Hunt, Rap. Comm. Mass Spectrom. $\underline{2}$ (1988) 59.

(5) M. Salehpour, D.E. Fishel and J.E. Hunt, Int. J. Mass Spectrom. Ion Proc. 84 (1988) R7.

(6) M. Salehpour, D.E. Fishe1 and J.E. Hunt, J. Appl. Phys. 64 (1988) 831.

(7) M. Salehpour, D.E. Fishel and J.E. Hunt, To appear in Phys. Rev. B. (1988).

(8) W. Brandt, A. Ratkowski and R.H. Ritchie, Phys, Rev. Lett. 33 (1974) 1325.

(9) J.W. Tape, H.H1. Gibson, J. Remillieux, R. Laubert and H.E. Wegner, Nucl. Instr. Meth. 132 (1976) 75.

(10) A. Hedin, R. Hakansson and B. Sundqvist, these proceedings. 